\title{
PENGARUH JUMLAH PENDUDUK, TINGKAT PENDIDIKAN DAN PDRB TERHADAP KEMISKINAN DI KOTA MALANG
}

\author{
Hafiz Nabawi \\ UPN “Veteran” Jawa Timur| hafiznabawi@gmail.com
}

\begin{abstract}
Abstrak : Pembangunan ekonomi harus berkesinambungan dengan perencanaan agar dapat berjalan sesuai dengan harapan yang ingin dituju yaitu kondisi perubahan perekonomian yang stabil juga menanggulangi kemiskinan. Berbagai cara dalam pengentasan kemiskinan harus dilakukan secara menyeluruh yang berdasarkan aspek masyarakat dengan cara yang terpadu khususnya di Kota Malang yang merupakan kota metropolitan kedua setelah Kota Surabaya harus memaksimalkan sektor-sektor unggulan agar pembangunan ekonomi dapat tersebar ke berbagai elemen masyarakat. Data yang digunakan merupakan data sekunder, yang dimana di dalam data tersebut terdapat kumpulan data time series yang telah dikutip dari tahun 2011-2018. Data bersumber dari BPS Kota Malang dan di analisis menggunakan analisis Regresi Linier Berganda dengan bantuan aplikasi SPSS untuk mengetahui pengaruh jumlah penduduk, tingkat pendidikan dan PDRB terhadap kemiskinan di Kota Malang. Berdasarkan hasil penelitian, menunjukkan bahwa jumlah penduduk mempengaruhi secara negatif sedangkan tingkat pendidikan tidak mempengaruhi secara positif dan untuk PDRB juga tidak mempengaruhi secara positif.
\end{abstract}

Keywords: Kemiskinan, Jumlah Penduduk, Tingkat Pendidikan, PDRB 


\section{Pendahuluan}

Pembangunan ekonomi dalam suatu daerah tertuju pada perubahan proses kearah lebih baik secara terus menerus untuk peningkatan perekonomian agar dapat menciptakan lapangan kerja guna memperkecil masalahmasalah pembangunan ekonomi dengan tujuan terciptanya kehidupan yang sejahtera bagi masyarakat khususnya di daerah. Di berbagai daerah di Indonesia, kemiskinan masih menjadi perbincangan di kalangan masyarakatnya. Fakta menunjukan pembangunan ekonomi belum mampu meredam kemiskinan diberbagai daerah khususnya di daerah yang tingkat kemiskinannya relatif naik dari tahun ke tahun.

Salah satu indikator utama keberhasilan pembangunan ekonomi adalah laju penurunan tingkat penduduk miskin. Efektifitas dalam menurunkan tingkat penduduk miskin merupakan pertumbuhan utama dalam memilih strategi pembangunan. Ukuran kemiskinan bisa disebut sebagai suatu standar tingkat hidup yang rendah, yaitu adanya suatu tingkat kekurangan materi pada sejumlah atau segolongan orang dibandingkan dengan standart kehidupan yang umum berlaku dalam masyarakat yang bersangkutan seperti standart kesehatan, moral, materi, dan sebagainya.

Realitanya, laju ekonomi yang tinggi belum tentu menjamin rendahnya tingkat kemiskinan di suatu daerah. Bahkan tidak memungkiri bahwa permasalahan kemiskinan masih menjadi focus dalam pembangunan ekonomi di kotakota besar. Salah satunya bisa kita lihat di Kota Malang. Kota Malang merupakan kota metropolitan kedua setelah Kota Surabaya di Jawa Timur yang memiliki luas wilayah 145.28 km2 (56.09 sq mi) dengan total jumlah penduduk sebanyak 
895.387 jiwa. Sektor pariwisata, Pendidikan, perdagangan jasa dan industri menjadi salah satu penunjang perekonomian di Kota Malang.

Berbagai upaya dalam menangani kemiskinan pun telah dilakukan oleh Pemkot Malang salah satunya adalah melalui pemberian bantuan sosial, bantuan pangan non tunai, normalisasi penduduk di Kawasan bantara sungai atau Daerah Aliran Sungai (DAS) dan pemberian pelatihan kepada pelaku UMKM sehingga akan turut mendongkrak roda perekonomian. Walaupun pengentasan kemiskinan ini dirasa belum sepenuhnya efektif, namun jumlah penduduk miskin di Kota Malang dari tahun ke tahun selalu mengalami penurunan.

Berdasarkan data dari Badan Pusat Statistik Kota Malang, pada tahun 2011 hingga 2018 telah terjadi penurunan jumlah penduduk miskin sebanyak 9.950 jiwa. Rata-rata jumlah penduduk miskin di Kota Malang berkurang sebanyak 1.421 jiwa tiap tahunnya, sehingga di akhir tahun 2018 lalu tercatat jumlah penduduk miskin yang tersisa sebanyak 35.490 jiwa. Hal ini dapat dikatakan bahwa Pemerintah Kota Malang dalam pengentasan kemiskinan cukup berhasil tetapi tetap mengejar target penekanan besaran angka kemiskinan sebesar 3,10 persen dan saat ini masih berada di angka 4,10 persen.

Berdasarkan data dari Badan Pusat Statistik Kota Malang, pada tahun 2011 hingga 2018 rata-rata pertumbuhan penduduk di Kota Malang mencapai 5.375.286 jiwa per tahun. Hingga pada 2018 tercatat jumlah penduduk Kota Malang sejumlah 866.118.000 jiwa. Dengan tingginya angka pertumbuhan penduduk ini Pemerintah Kota Malang harus mempunyai strategi yang berkesinambungan dengan keadaan tiap tahun juga target jangka menengah agar kebijakan yang ditetapkan dalam pelaksanaan pengentasan kemiskinan menjadi lebih terarah.

Selain jumlah penduduk, faktor lainnya yang dapat memengaruhi terjadinya persoalan kemiskinan yakni tingkat 
pendidikan baik formal maupun non-formal. Secara tidak langsung, tingkat pendidikan dapat memperbaiki produktivitas dan efisiensi pola kehidupan masyarakat. Sedangkan secara langsung, pendidikan dapat meningkatkan wawasan dan keterampilan sehingga meningkatkan pula produktivitas dan kreativitas masyarakat guna memperoleh kesejahteraan hidup yang dapat dilihat dari tingkat pendapatan maupun konsumsinya.

Faktor lain yang memengaruhi tingkat kemiskinan adalah Produk Domestik Regional Bruto, yang selanjutnya disebut PDRB. PDRB adalah jumlah nilai tambah bruto yang timbul dari seluruh sektor perekonomian di daerah tersebut. Tujuan perhitungan PDRB adalah untuk membantu pemerintah dalam menetapkan kebijakan atau perencanaan daerah, evaluasi hasil pembangunan, serta memuat informasi yang dapat menggambarkan kinerja perekonomian daerah.

Berdasarkan data dari Badan Pusat Statistik Kota Malang, PDRB Kota Malang dari tahun 2011 mengalami peningkatan hingga tahun 2018, sebesar 33.273.669,80 di tahun 2011 menjadi sebesar 49.502.475,23 di tahun 2018. Dengan kenaikan tertinggi di tahun 2015 hingga 2016 sebesar 2.351.774,8 dan tahun 2017 hingga 2018 sebesar 2.677.724,3. Bisa dilihat bahwa seiring dengan peningkatan PDRB juga terjadi penurunan kemiskinan. Tetapi harus dilakukan observasi lebih mendalam apakah dengan PDRB yang relatif naik semua masyarakat miskin bisa mendapat manfaatnya karena kemiskinan yang begitu dinamis di pola kehidupan masyarakat.

\section{Landasan Teori}

Banyaknya faktor yang memengaruhi tingkat kemiskinan, diantaranya yakni jumlah penduduk, tingkat pendidikan, dan PDRB. Maka dari itu dikembangkanlah fenomena diatas menjadi sebuah penelitian untuk melihat 
kontribusi faktor-faktor tersebut terhadap tingkat kemiskinan. Seperti penelitian yang pernah dilakukan oleh Janjua dan kamal (2012) yang menyimpulkan bahwa pendidikan dan pendapatan per kapita berpengaruh signifikan terhadap kemiskinan. Ada pula penelitian dari Cheema dan Sial (2012) yang menyebutkan bahwa pertumbuhan ekonomi dan ketimpangan pendapatan berpengaruh signifikan terhadap kemiskinan. Penelitian lain dari Ni Made Myanti Astrini A dan Ida Bagus Putu Purbadharmaja (2013) menyimpulkan bahwa secara simultan PDRB, Pendidikan dan pengangguran berpengaruh signifikan terhadap tingkat kemiskinan di Provinsi Bali juga secara parsial PDRB tidak berpengaruh signifikan terhadap tingkat kemiskinan, Pendidikan berpengaruh negative dan signifikan terhadap tingkat kemiskinan dan pengangguran berpengaruh positif dan signifikan terhdap tingkat kemiskinan. Hingga dalam penelitian terbaru yang dilakukan oleh Elda Wahyu Azizah, Sudarti dan Hendra Kusuma (2018) menunjukkan bahwa Pendidikan berpengaruh negatif dan signifikan terhadap kemiskinan, pendapatan perkapita berpengaruh negatif dan signifikan terhadap kemiskinan, jumlah penduduk berpengaruh positif dan signifikan terhadap kemiskinan.

Berdasarkan uraian tersebut maka dapat ditarik hipotesis sebagai berikut:

H1: Tingkat Pendidikan dan PDRB berpengaruh secara simultan dan parsial terhadap kemiskinan.

H2: Tingkat Pendidikan dan PDRB berpengaruh besar terhadap kemiskinan.

\section{Metode Penelitian}

Pendekatan yang digunakan dalam penelitian ini adalah pendekatan kuantitatif. Berdasarkan permasalahan, 
kajian teoritis, serta hasil penelitian sebelumnya maka penggambaran dalam penelitian ini, sebagai berikut:

\section{Gambar 1. Kerangka Pemikiran}

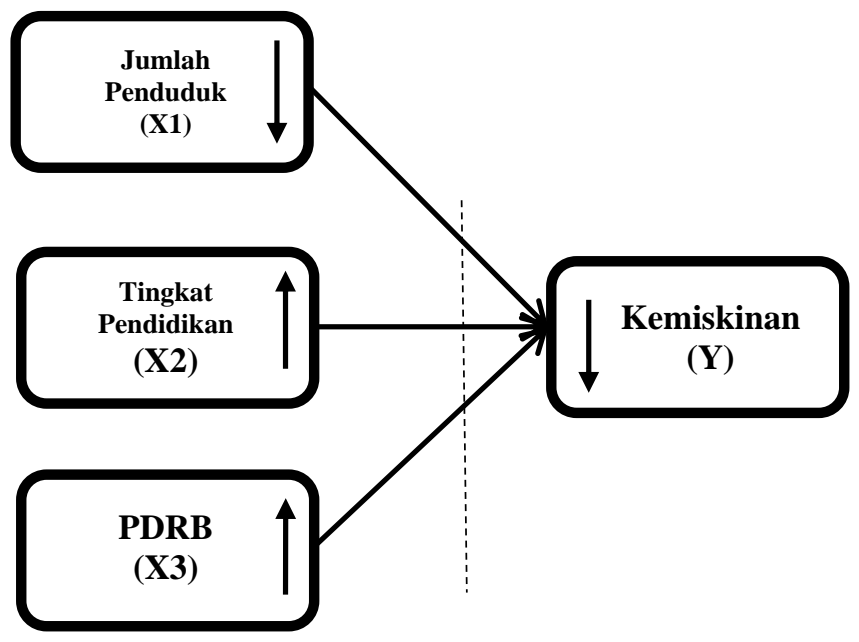

Penelitian ini dilakukan pada Kota Malang dengan objek penelitian adalah Jumlah penduduk, Tingkat Pendidikan dan PDRB setiap tahunnya pada periode 20112018. Variable terikat dari penelitian ini adalah Kemiskinan. Sedangkan variable bebas dalam penelitian ini adalah Jumlah Penduduk, Tingkat Pendidikan dan PDRB. Dalam penelitian ini peneliti mengambil data kemiskinan dari tahun 2011-2018 dikarenakan menyesuaikan dengan pengukuran PDRB seri 2010. Kemiskinan dinyatakan dalam satuan ribuan jiwa. Jumlah penduduk dinyatakan dalam satuan ribuan jiwa. Tingkat Pendidikan menggunakan rata-rata dari lama Pendidikan jenjang SD, SMP, SMA dan Sarjana yang 
dinyatakan dalam satuan tahun. Sedangklan PDRB dinyatakan dalam satuan juta Rupiah.

Sumber data diperoleh dari kantor instansi terkait yang berhubungan dengan penelitian ini yaitu Badan Pusat Statistik (BPS) untuk memperoleh data Kemiskinan, Jumlah Penduduk, Tingkat Pendidikan dan PDRB (Produk Domestik Regional Bruto) periode tahun 2011 - 2018. Teknik analisi yang digunakan adalah analisis regresi linier berganda. Bentuk persamaan regresi linier berganda sebagai berikut:

$\mathrm{Y}=\mathrm{b} 0+\mathrm{b} 1 \mathrm{X} 1+\mathrm{b} 2 \mathrm{X} 2+\mathrm{b} 3 \mathrm{X} 3+\mathrm{e}$

Dimana:

$\mathrm{Y}=$ Kemiskinan di Kota Malang

$\mathrm{X} 1$ = Jumlah Penduduk

X2 = Tingkat Pendidikan

$\mathrm{X} 3=\mathrm{PDRB}$

$=$ Konstanta

b1, b2,b3 = Koefisien Regresi

$\mathrm{e}=$ Variabel Pengganggu

\section{Pembahasan}

Wilayah Kota Malang terletak pada ketinggian antara 440-667 meter diatas permukaan air laut. Letaknya di tengahtengah Kabupaten Malang dan sisi selatan Pulau Jawa yang secara astronomis terletak 112,06o-112,07o Bujur Timur dan 7,06o-8,02o Lintang Selatan dan memiliki luas sebesar 145,28 
km2. Kota ini dibatasi oleh Kecamatan Singosari dan Kecamatan Karangploso di sisi utara, Kecamatan Pakis dan Kecamatan Tumpang di sisi Timur, Kecamatan Tajinan dan Kecamatan Pakisaji di sisi selatan dan Kecamatan Wangir dan Kecamatan Dau di sisi barat yang semuanya merupakan Kecamatan di Kota malang.

Uji autokorelasi bertujuan untuk mengetahui apakah ada atau tidaknya korelasi variabel didalam model prediksi dengan perubahan waktu. Salah satu cara dalam mendeteksi autokorelasi adalah menggunakan uji Lagrange Multiplier (LM test). Uji autokorelasi menyatakan bahwa nilai X2 hitung sebesar 0,56 lebih kecil dari nilai X2 tabel sebesar 14,06714 sehingga tidak terjadi gejala atau masalah autokorelasi.

Uji multikolinieritas digunakan untuk mengukur tingkat keeratan hubungan atau pengaruh antar variable bebas melalui besaran koefisien korelasi dengan cara membandingkan antara koefisien determinasi (R2) keseluruhan dengan nilai koefisien korelasi parsial semua variable bebas. Uji multikolinieritas menyatakan bahwa nilai correlation partial per variable bebas lebih kecil dari nilai R2 sebesar 0,988 maka dinyatakan tidak terjadi gejala multikolinieritas.

Uji heterokedastisitas bertujuan untuk menilai ada atau tidaknya kesamaan varian dari residual untuk semua pengamatan pada model regresi linier. Salah satu cara mendeteksinya dapat dilakukan dengan menggunakan uji korelasi rank spearman yang menyatakan bahwa seluruh variable bebas dalam penelitian ini memiliki nilai signifikan diatas 0,05 . Maka artinya seluruh variabel tidak mengalami gejala heterokedastisitas. Analisi regresi linier berganda 
bertujuan untuk menguji derajat kesamaan dan arah hubungan antara dua atau lebih variabel independent terhadap variabel dependen. Hasil analisi regresi linier berganda pada penelitian ini dapat dibuat suatu persamaan regresi linier berganda sebagai berikut:

$\mathrm{Y}=\mathrm{b} 0+\mathrm{b} 1 \mathrm{X} 1+\mathrm{b} 2 \mathrm{X} 2+\mathrm{b} 3 \mathrm{X} 3+\mathrm{e}$

$\mathrm{Y}=496,998-0,001 \mathrm{X} 1+0,721 \mathrm{X} 2+7,401 \mathrm{X} 3$

Untuk menguji kecocokan model regresi yang telah dihasilkan untuk melihat pengaruh variabel X1 dan X2 terhadap Y, maka digunakanlah uji F. Dalam penelitian ini, diperoleh nilai sig. Fhitung $=147.982>$ Ftabel $=6.59$ sehingga dapat disimpulkan bahwa H1 diterima dan Ho ditolak, artinya diduga terdapat pengaruh antara Jumlah Penduduk, Tingkat Pendidikan dan PDRB terhadap Kemiskinan di Kota Malang Tahun 2011-2018.

Uji t digunakan untuk menguji tingkat signifikasi dari variabel bebas secara individual dalam menerangkan variasi variabel tetap dengan menggunakan tingkat signifikan 0,05. Signifikansi hasil uji $t$ masing-masing variabel diketahui bahwa Jumlah Penduduk memiliki nilai Thitung= -3,599 yang berarti lebih kecil dari Ttabel =2,77645. Hal ini menunjukkan bahwa Jumlah Penduduk berpengaruh terhadap Kemiskinan di Kota Malang Tahun 2011-2018. Dengan demikian, H1 diterima. Sementara itu, Tingkat Pendidikan memiliki nilai Thitung = 1,300 yang berarti lebih kecil dari nilai Ttabel $=$ 2,77645. Hal ini menunjukkan bahwa Tingkat Pendidikan tidak berpengaruh terhadap Kemiskinan di Kota Malang Tahun 2011-2018. Dengan demikian, H1 ditolak. Dan PDRB memiliki nilai Thitung $=1,955$ yang berarti lebih kecil dari nilai Ttabel $=2,77645$. Hal ini menunjukkan bahwa PDRB 
tidak berpengaruh terhadap Kemiskinan di Kota Malang Tahun 2011-2018. Dengan demikian H1 ditolak.

Hasil dari penelitian ini menunjukkan bahwa Jumlah Penduduk berpengaruh secara nyata terhadap kemiskinan di Kota Malang dengan asumsi bahwa Jumlah Penduduk turun maka kemiskinan tetap naik hal tersebut dikarenakan jumlah penduduk tidak dibarengi dengan pengembangan kualitas sumber daya manusia menyebabkan tidak memperoleh pekerjaan dan menganggur dan akhirnya menimbulkan kemiskinan. Juga tidak seimbangnya angka kelahiran dan kematian, struktur umur yang berusia dewasa dan berusia muda, distribusi penduduk yang tidak merata antara kota dan desa dan kualitas penduduk.

Selain itu di Kota Malang banyak para pendatang yang hanya singgah untuk mencoba membuka usaha dikarenakan Kota Malang memiliki daya tarik wisatawan apalagi bersebelahan dengan Kota Batu yang memiliki banyak tempat wisata yang mengakibatkan banyak orang yang berdatangan ke Kota Malang untuk singgah dan juga terdapat sebagian penduduk yang berpindah kota untuk memperbaiki keadaan ekonominya karena kalah saing dengan para pendatang yang membuka usaha. Ditambah masih banyaknya masyarakat yang menggantungkan hidupnya menjadi pengemis dikarenakan malas untuk bekerja dengan kurangnya pengetahuan dan keadaan ekonomi yang memaksa satu keluarga untuk menjadi pengemis. Maka hal tersebut yang menyebabkan masih naiknya kemiskinan di Kota Malang meskipun jumlah penduduk telah turun. Sedangkan Tingkat Pendidikan tidak berpenagruh secara positif terhadap kemiskinan dikarenakan pendidikan tidak mempengaruhi seseorang untuk membuka usahanya sendiri atau untuk memperbaiki perekonomiannya dan produktivitas seseorang tidak didasarkan atas tingkat pendidikan yang ditempuh. Selain itu di Kota Malang banyak 
masyarakat pendatang yang menempuh Pendidikan namun setelah lulus mereka kembali ke kota asalnya masing-masing dan juga masih ada kendala dalam sistem pendidikannya yang terbukti masih rendahnya angka kelulusan di berbagai tingkat Pendidikan sehingga membuat laju Pendidikan menjadi lambat yang dalam jangka panjang mempengaruhi tenaga kerja yang dihasilkan sehingga menyebabkan kemiskinan. Dan variabel PDRB tidak berpengaruh secara positif terhadap kemiskinan dikarenakan dikarenakan pertumbuhan ekonomi yang tidak merata atau tidak menyebar di semua elemen masyarakat dan banyaknya pendatang di Kota Malang menyebabkan bertambahnya tempat penginapan dan wisata sehingga menimbulkan usaha masyarakat yang meningkat tetapi didominasi masyarakat kalangan menengah kebawah dengan begitu tidak mempengaruhi kemiskinan di Kota Malang.

\section{Penutup}

Variabel Jumlah Penduduk mempengaruhi kemiskinan di Kota Malang dengan asumsi bahwa jumlah penduduk turun maka kemiskinan tetap naik hal tersebut disebabkan tidak seimbangnya struktur umur antara yang berusia muda dan dewasa, banyaknya pendatang yang singgah dan membuka usaha dan masih banyaknya pengemis di Kota Malang. Variabel tingkat pendidikan tidak mempengaruhi kemiskinan di Kota Malang hal tersebut dikarenakan angka kelulusan yang masih rendah dan tingkat pendidikan tidak mempengaruhi keadaan perekonomian seseorang sebab banyaknya masyarakat yang menciptakan lapangan usahanya sendiri tanpa melihat tingkat pendidikan yang ditempuh maka tingkat pendidikan tidak secara langsung mempengaruhi kemiskinan di Kota Malang. Variabel PDRB tidak mempengaruhi kemiskinan di Kota Malang hal tersebut dikarenakan pertumbuhan ekonomi yang tidak merata dan menyebar ke berbagai elemen 
masyarakat dan mengakibatkan ketimpangan. Maka PDRB tidak secara langsung mempengaruhi kemiskinan di Kota Malang.

Berdasarkan hasil dan kesimpulan dari penelitian ini, maka saran yang dapat disampaikan kepada pemerintah kota, dalam hal ini dengan melihat jumlah penduduk turun dan kemiskinan tetap naik seharusnya bisa mengelola pemerataan penduduk antara usia produktif dan tidak produktif juga penyuluhan dan rehabilitasi terhadap pengemis, Upaya pemerataan wajib sekolah 12 tahun juga program pelatihan dan sertifikasi bagi masyarakat. Dan juga pemerintah harus bisa menanggulangi seluruh sektor pada PDRB secara merata di berbagai kalangan masyarakat agar kemiskinan dapat dapat ditanggulangi dan pemerintah dapat memberikan program bantuan khusus kepada masyrakat miskin berupa bantuan tunai atau non tunai. Bagi peneliti selanjutnya diharapkan dapat menambah variabel lainnya agar dapat secara jelas dan dipercaya dalam mengukur kemiskinan di Kota Malang karena ukuran kemiskinan yang bersifat dinamis.

\section{Daftar Referensi}

Agrawal, Pradeep. 2015. Reducing Poverty in India: The Role of Economic Growth. IEG Working Paper No. 349.

Arsyad, Lincoln. 2010. Pengantar Perencanaan dan Pembangunan Ekonomi Daerah. Yogyakarta: BPFE

Astrini, N. M. (2013). Pengaruh PDRB, Pendidikan dan Pengangguran Terhadap Kemiskinan di Provinsi Bali. E-Jurnal EP Unud, 2 (8): 384-392.

Azizah, E. W. (2018). Pengaruh Pendidikan, Pendapatan Perkapita dan Jumlah penduduk Terhadap 
kemiskinan di Provinsi Jawa Timur. Jurnal Ilmu Ekonomi, vol 2 jilid 1 hal. 167-180.

Case, K. E.,\&Fair, R. C. (2010). Prinsip-Prinsip Ekonomi, Ed Ke8, J.1. Jakarta: Penerbit Erlangga.

Checchi, Daniele. 2006. The Economics of Education. Cambridge University.

Cheema, A. R., and Sial M. H. 2012. Poverty, Income Inequality, and Growth in Pakistan: A Pooled Regression Analysis. The Lahore Josurnal of Economics: Vol. 17(2), 137-157

Dama, Himawan Yudhistira dkk. 2016. Pengaruh Produk Domestik Regional Bruto (Pdrb) Terhadap Tingkat Kemiskinan Di Kota Manado (Tahun 2005-2014). Jurnal Berkala llmiah Efisiensi. Vol. 16(3): 549-561

Dowling, J. Malcolm dan Valenzuela, Rebecca. 2010. Economic Development in Asia. Second Edition. Singapore: CENGAGE Learning.

Ginting S, dkk. 2008. Pembangunan Manusia di Indonesia Dan Faktor-Faktor Yang Mempengaruhinya. Jurnal Perencanaan \& Pengembangan Wilayah. Vol.4. No. 1 Hal 17-24.

Giovanni, R. (2018). Analisis Pengaruh PDRB, Pengangguran dan Pendidikan Terhadap Kemiskinan di Pulau Jawa Tahun 2009-2016. Economics Development Analysis Journal, $7(1)$.

Haughton, Jonathan dan Khandker, Shahidur R. 2010. Pedoman tentang Kemiskinan dan Ketimpangan. Terjemahan oleh Tim Penerjemah World Bank. 2012. Jakarta: Salemba Empat. 
Janjua, P. Z., and Kamal, U.A. (2012). The role of education and income in poverty alleviation: A cross-country analysis. Lahore Journal of Economics. Vol. 16(1): 143-172.

Jhingan, M.L. 2004. Ekonomi Pembangunan dan Perencanaan. Jakarta: Rajawali Press.

Susanti, S. (2013). Pengaruh PDRB, Pengangguran dan IPM Terhadap Kemiskinan di Jawa Barat. Jurnal Matematika Integratif, Vol 9 No 1 pp. 1-18.

Todaro, Michael P. dan Stephen C. S. (2000). Pembangunan Ekonomi di Dunia Ketiga Edisi Ketujuh. Jakarta: Erlangga.

Todaro, Michael P. dan Stephen C. Smith. Tanpa Tahun. Pembangunan Ekonomi Edisi Kesembilan. Terjemahan oleh Harus Munandar. 2006. Jakarta: Erlangga

Usman, N. D. (2006). Pendekatan Populer Dan Praktis Ekonometrika Untuk Analisis Ekonomi dan Keuangan. Jakarta: FE UI.

Usman, U. (2018). Pengaruh Jumlah Penduduk, Pengangguran dan Pertumbuhan Ekonomi Terhadap Kemiskinan di Provinsi Kepulauan Riau. Jurnal Ekonomi Regional Unimal, Volume 01 Nomor 02.

Wahyuniarti, H. S. (2010). Dampak Pertumbuhan Ekonomi Terhadap Penurunan Jumlah Penduduk Miskin. Jurnal Institut Pertanian Bogor. 